\title{
Valve-Sparing Aortic Root Replacement by Congenital Heart Surgeons: A Single Center Experience.
}

\author{
Reilly D. Hobbs ${ }^{1}$, Megan Schultz ${ }^{2}$, Megan Loney ${ }^{2}$, Sonaal Verma ${ }^{2}$, Julia Xiong ${ }^{2}$, Eric \\ Smith $^{2}$, Richard G. Ohye ${ }^{2}$, Edward Bove ${ }^{2}$, and * Ming-Sing ${ }^{2}$ \\ ${ }^{1}$ University of Utah Hospital \\ ${ }^{2}$ University of Michigan Department of Surgery
}

February 9, 2022

\begin{abstract}
Background Aortic root dilatation and aortic insufficiency can occur in patients with prior conotruncal defect surgery, the Ross procedure, and connective tissue disease (CTD). Valve-sparing aortic root replacement (VSRR) is an excellent choice for these young patients. We present the outcomes of young patients undergoing VSRR by congenital heart surgeons at a single center. Methods A single center retrospective chart review from April 2008 - April 2021 was performed. Patients with aortic root and valve pathology who underwent VSRR were identified. A total of 49 patients were identified by using the hospital surgical database. Three VSRR techniques were utilized during the study period; aortic valve-sparing root remodeling (Group 1, 7 patients), aortic valve-sparing root reimplantation (Group 2, 32 patients), and a modified root remodeling procedure utilizing a geometric annuloplasty ring (Group 3, 10 patients). Patient characteristics, post-VSRR echocardiogram studies and need for intervention, and survival were analyzed. Results Long-term survival after VSRR is excellent with only one death related to cardiac causes. Valve degeneration remains a concern with 13 patients (26\%) requiring subsequent aortic valve replacement over the study period. Risk factors for aortic valve reintervention were the aortic root remodeling technique, mild or greater immediate post-operative aortic insufficiency and higher post-operative mitral insufficiency. Follow-up was significantly longer in Group 1 patients compared to Groups 2 and 3. Conclusions Valve-sparing aortic root replacement is safely performed by congenital heart surgeons in a heterogeneous patient population. Valve degeneration remains a concern and greater than trivial post-operative aortic insufficiency should prompt further attempts at valve repair or replacement.
\end{abstract}

\section{Valve-Sparing Aortic Root Replacement by Congenital Heart Surgeons: A Single Center Ex- perience.}

Running Head: VSRR by Congenital Heart Surgeons

Authors : Reilly D. Hobbs, MD, MBS ${ }^{1,2}$; Megan Schultz, MD ${ }^{1}$; Megan Loney ${ }^{1}$; Sonaal Verma ${ }^{1}$; Julia Xiong$^{1}$; Eric Smith, PA-C ${ }^{1}$; Richard G. Ohye, $\mathrm{MD}^{1}$; Edward L. Bove, $\mathrm{MD}^{1}$; Ming-Sing Si, MD ${ }^{1}$.

1: Department of Cardiac Surgery, Division of Pediatric Cardiovascular Surgery, University of Michigan, Michigan Medicine, Ann Arbor, Michigan

2: Division of Cardiothoracic Surgery, Section of Pediatric Cardiac Surgery, Primary Children's Hospital, University of Utah, Salt Lake City, Utah

Presentation: The Society of Thoracic Surgeons, Virtual Format, January 31, 2021.

Word count: 4261

Direct Correspondence to: Reilly D. Hobbs MD, MBS, Assistant Professor, Pediatric Cardiothoracic Surgery, Primary Children's Hospital, University of Utah, 100 N Mario Capecchi Drive, Suite 2200, Salt 
Lake City, UT 84112; E-mail: Reilly.Hobbs@hsc.utah.edu; Phone: (801) 662-5562; Fax: (801) 662-5566

\section{Classifications: 20}

\section{Background}

Aortic root dilatation and aortic insufficiency can occur in patients with prior conotruncal defect surgery, the Ross procedure, and connective tissue disease (CTD). Valve-sparing aortic root replacement (VSRR) is an excellent choice for these young patients. We present the outcomes of young patients undergoing VSRR by congenital heart surgeons at a single center.

\section{Methods}

A single center retrospective chart review from April 2008 - April 2021 was performed. Patients with aortic root and valve pathology who underwent VSRR were identified. A total of 49 patients were identified by using the hospital surgical database. Three VSRR techniques were utilized during the study period; aortic valve-sparing root remodeling (Group 1, 7 patients), aortic valve-sparing root reimplantation (Group 2, 32 patients), and a modified root remodeling procedure utilizing a geometric annuloplasty ring (Group 3, 10 patients). Patient characteristics, post-VSRR echocardiogram studies and need for intervention, and survival were analyzed.

\section{Results}

Long-term survival after VSRR is excellent with only one death related to cardiac causes. Valve degeneration remains a concern with 13 patients (26\%) requiring subsequent aortic valve replacement over the study period. Risk factors for aortic valve reintervention were the aortic root remodeling technique, mild or greater immediate post-operative aortic insufficiency and higher post-operative mitral insufficiency. Follow-up was significantly longer in Group 1 patients compared to Groups 2 and 3.

\section{Conclusions}

Valve-sparing aortic root replacement is safely performed by congenital heart surgeons in a heterogeneous patient population. Valve degeneration remains a concern and greater than trivial post-operative aortic insufficiency should prompt further attempts at valve repair or replacement.

\section{Graphical/Visual Abstract (second page)}




\section{9 patients undergoing valve-sparing aortic root replacement (2008-2021)}

in a single congenital heart center

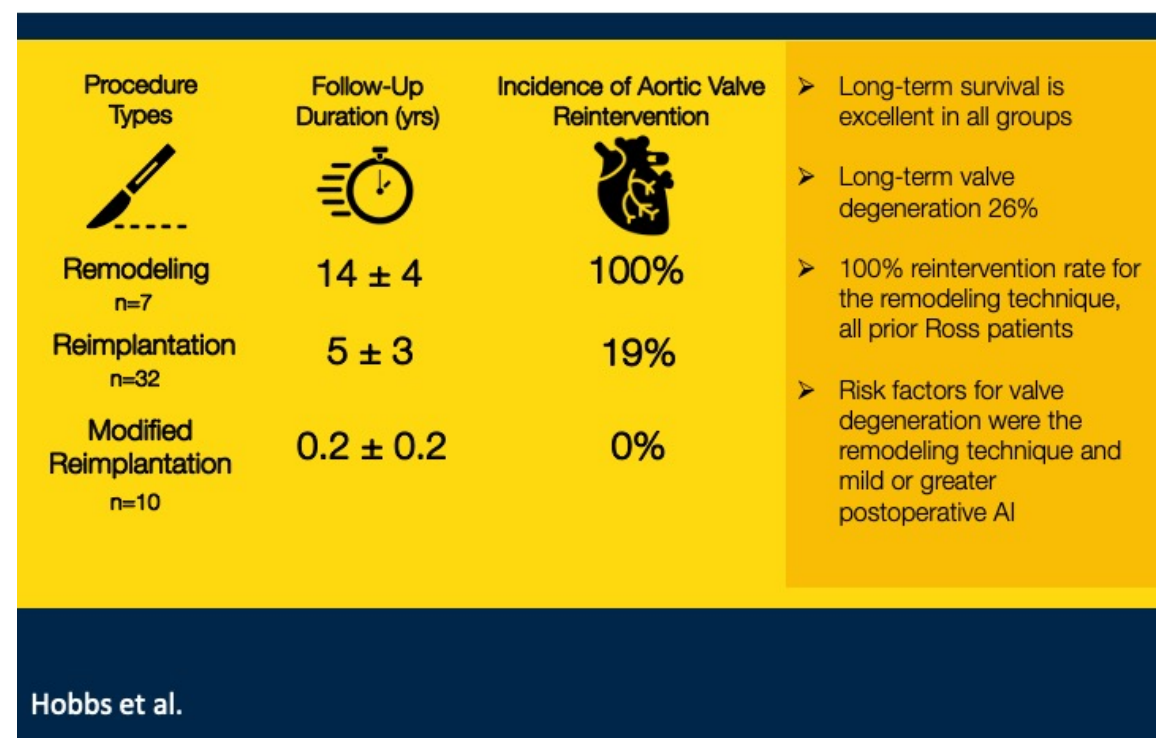

\section{Background}

Aortic root and valve disease can present in young patients, who seek care at congenital heart centers Aortic root aneurysm can occur in patients with prior conotruncal defect surgery, the Ross procedure, and connective tissue diseases. ${ }^{1,2}$ When left untreated, aortic root dilatation in these patients may lead to the development of aortic insufficiency, heart failure, dissection, rupture, and death. ${ }^{3}$ Due to the young age of these patient populations, congenital heart surgeons must be familiar with the management and repair of aortic root and valve disease.

Valve-sparing aortic root interventions are appealing to minimize future valve interventions and/or systemic anticoagulation. However, their outcomes are poorly defined due to the heterogeneity and complexity of this population. In this retrospective, single-center study, we describe the outcomes of three different VSRR procedures and determine the factors associated with the need for subsequent reintervention.

\section{Methods}

\section{PATIENTS AND METHODS}

This study was deemed exempt by the University of Michigan Institutional Review Board and the need for Informed Written Consent was waived due to its retrospective nature.

\section{Data Source}

We identified patients who underwent valve-sparing aortic root surgery at C.S. Mott Children's Hospital, University of Michigan Medical Center, for the treatment of neoaortic dilatation after the Ross procedure, aortic dilatation secondary to connective tissue disease, or aortic dilatation after prior conotruncal heart surgery between the years 2008 and 2021.

\section{Patient Population}

Patients who underwent valve-sparing aortic root surgery were identified. We then collected preoperative, operative, and postoperative characteristics from institutional and regionally-shared medical records of each patient. 


\section{Definitions}

\section{Operative Techniques and Clinical Management}

Patients were divided into three groups according to the type of valve-sparing root replacement technique utilized; Group 1 patients received a root remodeling (Yacoub) procedure, as described elsewhere. Group 2 patients underwent the reimplantation technique (David procedure). ${ }^{17}$ Group 3 patients underwent placement of a trileaflet aortic annuloplasty ring (HAART 300, Biostable), leaflet plication, and root remodeling procedure. The details of aortic annuloplasty ring sizing and placement have been previously reported. ${ }^{18}$ The root remodeling procedure was then performed using a Valsalva graft that was sized approximately 5 $\mathrm{mm}$ more than the size of the ring that was implanted. The left coronary button was then reimplanted, followed by the distal anastomosis of the graft to the ascending aorta. Cardioplegia was then infused to pressurize the root, the site for the right coronary button was determined, and the right coronary artery was implanted.

\section{Outcomes}

Patient survival, postoperative aortic insufficiency (AI) grade determined by echocardiogram or cardiac MRI, and need for aortic valve reintervention were determined for each patient.

\section{Statistical Analysis}

Data analysis was performed using SPSS 27 software (Armonk, NY). Data are presented as median for continuous data and number (\%) for categorical data. Univariate comparisons across different groups of surgical techniques were performed using the $\chi^{2}$ test for categorical data and ANOVA. A p-value $<0.05$ (2-tailed) was considered statistically significant.

\section{Results}

We identified 49 patients who underwent a valve-sparing root replacement during our study period. Twentyfour patients had a history of the Ross procedure, 17 patients had a history of connective tissue disease, and eight patients had a history of congenital heart defect. Group 1 was comprised of seven patients who underwent the aortic root remodeling technique, Group 2 was comprised of 32 patients who underwent the aortic root reimplantation technique, and Group 3 was comprised of ten patients who underwent an aortic root remodeling technique with a rigid aortic annuloplasty ring. All seven patients in Group 1 had undergone a prior Ross procedure. Group 2 and Group 3 were patients with a history of connective tissue disease, prior conotruncal heart surgery, congenital heart disease, or a prior Ross procedure. Mean follow-up was significantly different between groups $(\mathrm{p}<0.001)$. Group 1 and Group 2 patients had 7- and 14-year follow-up respectively and Group 3 had 1-year follow-up. The traditional aortic root remodeling technique has been largely abandoned in our institution and replaced with the aortic root remodeling technique with rigid annuloplasty ring since 2018. Aortic root reimplantation has been largely replaced as well, but is still used for selected patients based on surgeon preference and patient anatomy. Patient demographics were similar among groups with a median age of 19 years (range 8-32) and 87\% male sex (table 1). There were no significant differences between the cardiopulmonary bypass and aortic cross-clamp times between groups 1 and 2; however, cardiopulmonary bypass times and aortic cross-clamp times were significantly higher in group $3(\mathrm{p}<0.001)$. Group 1 and 3 were more likely to have a history of the Ross procedure $(\mathrm{p}=$ $0.003)$, and group 2 was more likely to have a history of connective tissue disease $(\mathrm{p}=0.21)$. Group 1 was more likely to require subsequent aortic valve replacement, with all Group 1 patients requiring aortic valve replacement over the study period $(\mathrm{p}<0.001)$. Group 3 did not have any required valve reinterventions during the study period. Group 3 was also more likely to have undergone aortic valve leaflet plication as part of their procedure $(\mathrm{p}=0.004)$. There were no significant differences between aortic annulus measurements preoperatively $(\mathrm{p}=0.741)$, but there was a significant difference in postoperative aortic annulus measurement $(\mathrm{p}=0.01)$ Preoperative AI grades were similar between groups and were 2, 1.7, and 2.4 respectively $(\mathrm{p}=$ 0.2 ). However, immediate postoperative AI grades were significantly different between groups: $2.2,1.2$, and 1.2 respectively $(\mathrm{p}=0.3)$. The most recent $\mathrm{AI}$ grades in patients from group 2 and 3 who did not require 
subsequent aortic valve replacement were similar $(\mathrm{p}=0.9)$. Survival was good in all groups with one early mortality due to hemorrhage and one late mortality from malignancy.

Thirteen patients required aortic valve replacement after their valve-sparing root replacement during the study period. According to procedure type, all seven patients (100\%) in Group 1 required valve replacement, six patients $(19 \%)$ in Group 2 required aortic valve replacement, and no patient required valve replacement in Group 3 ( $\mathrm{p}<0.001)$. Average time to aortic valve replacement after valve-sparing aortic root replacement between Group 1 and Group 2 was 4.7 and 3.4 years, respectively $(\mathrm{p}=0.6)$. History of connective tissue disease, prior Ross procedure, concomitant procedures, and prior sternotomy were not associated with increased risk for reintervention. Patients who required subsequent valve reintervention had significantly longer follow-up $(\mathrm{p}<0.001)$, larger postoperative aortic annulus measurements $(\mathrm{p}=0.012)$, and longer cardiopulmonary bypass $(\mathrm{p}=0.01)$ and aortic cross clamp times $(\mathrm{p}=0.003)$. There was no significant difference in preoperative AI grades; however, patients requiring future aortic valve replacement had significantly higher immediate postoperative AI grades $(\mathrm{p}<0.001)$. Six of seven patients with greater than mild aortic insufficiency on immediate postoperative echocardiogram required subsequent aortic valve replacement $(\mathrm{p}<0.001)$. Postoperative mitral regurgitation was also higher in patients who eventually required aortic valve replacement $(\mathrm{p}=0.05)$

\section{Conclusions}

Aortic root dilatation, with or without resultant aortic insufficiency, is commonly encountered in congenital heart surgery. The optimal management of these young patients is challenging for clinicians due to their heterogeneity and often complex surgical histories. The development of standardized guidelines for surgical interventions for these patients is also challenging due to their relative heterogeneity and infrequency in comparison to adult aneurysmal disease and connective tissue aneurysmal disease. Current evidence also suggests that the complications of dissection and rupture are less common than in adults with de novo aortic root dilatation. ${ }^{9}$ Many clinicians with experience treating these patients, including the authors of this report, advocate for the consideration of surgical intervention when aneurysms reach 5-5.5 centimeters or when there are concomitant surgical lesions that require interventions, such as aortic insufficiency causing significant heart dysfunction or concomitant right sided heart disease. ${ }^{10,11}$

Most patients in our center have a history of connective tissue disease, a prior Ross procedure, unrepaired congenital heart disease, or prior congenital heart surgery. The Bentall procedure with either a mechanical or bioprosthetic valve has been the historical treatment of choice for patients with aortic root dilatation with or without aortic insufficiency. The Bentall procedure offers a straight-forward surgical technique and excellent long-term results with the use of mechanical valves; however, the late complications of bleeding, valve reintervention, and thrombosis remain concerning. ${ }^{12}$ The Bentall procedure with the use of bioprosthetic valved conduits offers patients the avoidance of systemic anticoagulation and reasonable long-term freedom from reintervention. A recent study by Chirichilli demonstrated a freedom from reoperation at 16 years of $74.7 \%$. While these results are impressive and makes this an appealing choice for older patients, the likelihood of reintervention for patients with decades of life expectancy is a near certainty. For these reasons, valve-sparing root replacement is an appealing treatment strategy and may be underutilized. ${ }^{13-15}$

Optimal technique for valve-sparing root replacement is another area of debate. Extensive literature has been published on the indications and efficacy of valve-sparing aortic root replacements in adult patients with aortic root dilatation; however, less literature is available guiding clinicians on the optimal indications for intervention in patients with a history of prior congenital heart surgery with only small case series published with mixed results. ${ }^{7,}$ 16-19 Although other less common surgical techniques have been described, valve-sparing root replacement techniques can be grouped as either aortic root type reimplantation or aortic root type remodeling. The aortic root replacement technique is generally believed to be superior to the aortic root remodeling technique as it provides circumferential support of the aortic root and basal ring. The aortic root remodeling technique replaces the aortic sinuses but does not provide support to the intercommissural triangles and basal ring. Numerous studies have shown the aortic root reimplantation technique to have lower rates of reoperation and recurrent aortic insufficiency ${ }^{16}$. Like our results with the aortic root remod- 
eling procedure, a study by Roubertie and colleagues examining results of valve-sparing operations in 23 children with connective tissue disease found that the aortic root reimplantation technique was superior to the aortic root remodeling technique. They observed a nearly $50 \%$ reintervention rate for patients treated with the aortic root remodeling technique. ${ }^{16}$ The largest series examining the results of valve-sparing aortic root replacement in children was published by Fraser et al in 2018 and examines the results of 100 consecutive pediatric patients. ${ }^{20}$ Most patients in this series had a history of connective tissue disease (90\%) with the remaining patients having a history of congenital heart surgery. Like our results comparing the reimplantation and remodeling techniques, they observed superior freedom from reintervention with the aortic root reimplantation technique compared to the aortic root remodeling technique. Late complications of aortic insufficiency and aneurysm formation remained a concern. ${ }^{20}$

Despite the seemingly clear advantage of the aortic root reimplantation technique, it is technically more challenging to perform an adequate external aortic root dissection, especially in patients who have undergone prior arterial switch operations or the Ross procedure. The aortic root remodeling technique obviates the need for extensive external root dissection, but durability is concerning. The use of a rigid geometric subannular annuloplasty ring can standardize aortic valve repair and aortic root replacement techniques, and its utilization during the aortic root remodeling technique provides annular and intercommissural triangle stabilization while avoiding the extensive external aortic root dissection necessary for the reimplantation technique.

This study examined the outcomes of valve-sparing aortic root replacement in a congenital heart center. Over our study period we utilized three different valve-sparing techniques, (1) the traditional aortic root remodeling technique, (2) the aortic root reimplantation technique, and (3) a modified aortic root remodeling technique with the use of a rigid annuloplasty ring. The traditional aortic root remodeling technique (Group 1) was only utilized in patients with aortic root dilatation after the Ross procedure and was associated with a $100 \%$ reintervention rate over our study period, whereas the aortic root reimplantation group (Group 2) and the remodeling group with annuloplasty ring (Group 3) had 19\% and $0 \%$ respectively. These results should be interpreted with caution as the average follow-up was significantly longer in Group 1 (17 years) compared to Group 1 (8 years) or Group 3 (0.7 years). Nevertheless, the average length of time to aortic valve reintervention in Group 1 and Group 2 was 5 and 3 years respectively. The largest risk for aortic valve replacement after valve-sparing root surgery in our study, as well as other studies, was higher degrees of postoperative aortic insufficiency. The immediate postoperative degree of aortic insufficiency was less in Group $3(\mathrm{p}=0.03)$ which suggests that this technique will have acceptable durability. Similar to other studies, our findings suggest that the traditional aortic root remodeling procedure should be avoided due to poor durability.

This study does have significant limitations. First, the technique utilized over the study period was subject to surgeon preference which could impact the overall results. Secondly, there are significant differences in the follow-up duration between the three groups and only short-term follow-up is available for Group 3 patients.

In summary, valve-sparing aortic root replacement can be safely performed for a variety of indications by congenital heart surgeons. However, there is continued risk for valve failure over time. The traditional aortic root remodeling technique, when applied to patients with dilatation following the Ross procedure, should be avoided as this cohort of patients had a $100 \%$ failure rate over our study period. The aortic root reimplantation technique has acceptable results; however, there was a $20 \%$ rate of valve failure over our study period. The aortic root remodeling technique combined with the use of geometric ring annuloplasty has good short-term results; however, longer follow-up is needed to fully delineate its durability and effectiveness in comparison to the aortic root reimplantation technique.

Table 1. Stats by procedure. Group $1=$ Aortic Root Remodeling $2=$ Aortic Root Reimplantation. Group $3=$ Aortic Root Reimplantation with rigid annuloplasty ring. 


\begin{tabular}{|c|c|c|c|c|c|}
\hline $\begin{array}{l}\text { Variable } \\
\text { Median + std } \\
\text { or } \mathbf{n}(\%)\end{array}$ & Total $n=49$ & Group $1 \mathrm{n}=7$ & Group $2 \mathrm{n}=32$ & Group $3 \mathrm{n}=10$ & $p$-value \\
\hline Age, years & $19 \pm 6$ & $19 \pm 6$ & $19 \pm 6$ & $21 \pm 4$ & 0.674 \\
\hline Male sex & $43(87)$ & $7(100)$ & $27(84)$ & $9(90)$ & 0.506 \\
\hline $\begin{array}{l}\text { Weight at } \\
\text { Operation, kg }\end{array}$ & $71 \pm 25$ & $67 \pm 20$ & $71 \pm 29$ & $72 \pm 16$ & 0.923 \\
\hline $\begin{array}{l}\text { Postop Length } \\
\text { of Stay, days }\end{array}$ & $5 \pm 2$ & $6 \pm 3$ & $6 \pm 2$ & $4 \pm 1$ & 0.156 \\
\hline $\begin{array}{l}\text { Follow-Up, } \\
\text { years }\end{array}$ & $5 \pm 5$ & $14 \pm 4$ & $5 \pm 3$ & $0.2 \pm 0.2$ & $<0.001$ \\
\hline $\begin{array}{l}\text { Follow-Up to } \\
\text { Last Known } \\
\text { Alive, years }\end{array}$ & $8 \pm 6$ & $17 \pm 3$ & $8 \pm 3$ & $0.7 \pm 0.5$ & $<0.001$ \\
\hline $\begin{array}{l}\text { Valve } \\
\text { Reintervention }\end{array}$ & $13(27)$ & $7(100)$ & $6(19)$ & $0(0)$ & $<0.001$ \\
\hline $\begin{array}{l}\text { Time to Rein- } \\
\text { tervention, } \\
\text { years }\end{array}$ & $4 \pm 4$ & $5 \pm 5$ & $3 \pm 3$ & - & 0.606 \\
\hline CTD & $18(37)$ & $0(0)$ & $16(50)$ & $2(20)$ & 0.021 \\
\hline Death & $2(4)$ & $1(14)$ & $1(3)$ & $0(0)$ & 0.307 \\
\hline $\begin{array}{l}\text { Time to } \\
\text { Death, years }\end{array}$ & $5 \pm 8$ & 11 & 0 & - & - \\
\hline $\begin{array}{l}\text { Follow-Up to } \\
\text { Most Recent } \\
\text { Echo, years }\end{array}$ & $5 \pm 5$ & $10 \pm 8$ & $5 \pm 4$ & $0.4 \pm 0.4$ & $<0.001$ \\
\hline $\begin{array}{l}\text { Prior Ross } \\
\text { Procedure }\end{array}$ & $25(51)$ & $7(100)$ & $11(34)$ & $7(70)$ & 0.003 \\
\hline $\begin{array}{l}\text { Leaflet } \\
\text { Manipulation } \\
\text { Etiology }\end{array}$ & $15(31)$ & $3(43)$ & $5(16)$ & $7(70)$ & 0.004 \\
\hline Congenital & $21(49)$ & $0(0)$ & $15(47)$ & $6(60)$ & 0.509 \\
\hline Bicuspid & $14(33)$ & $1(100)$ & $9(28)$ & $4(40)$ & \\
\hline Acquired & $7(16)$ & $0(0)$ & $7(22)$ & $0(0)$ & \\
\hline Other & $1(2)$ & $0(0)$ & $1(3)$ & $0(0)$ & \\
\hline $\begin{array}{l}\text { Redo } \\
\text { Sternotomy }\end{array}$ & $28(57)$ & $7(100)$ & $14(44)$ & $7(70)$ & 0.016 \\
\hline $\begin{array}{l}\text { Concomitant } \\
\text { Procedure }\end{array}$ & $31(63)$ & $4(57)$ & $18(56)$ & $9(90)$ & 0.145 \\
\hline $\begin{array}{l}\text { Preop AI }(0= \\
\text { none, } 1= \\
\text { trivial, } 2= \\
\text { mild, } 3= \\
\text { moderate, } 4= \\
\text { severe })\end{array}$ & $1.9 \pm 1$ & $2.4 \pm 9.7$ & $2.1 \pm 0.9$ & $2.4 \pm 9.7$ & 0.203 \\
\hline $\begin{array}{l}\text { Greater Than } \\
\text { Trivial Preop } \\
\text { AI }\end{array}$ & $34(69)$ & $5(71)$ & $21(66)$ & $8(80)$ & 0.685 \\
\hline $\begin{array}{l}\text { Greater Than } \\
\text { Mild Preop AI }\end{array}$ & $16(33)$ & $4(57)$ & $7(22)$ & $5(50)$ & 0.083 \\
\hline
\end{tabular}




\begin{tabular}{|c|c|c|c|c|c|}
\hline $\begin{array}{l}\text { Variable } \\
\text { Median + std } \\
\text { or } \mathbf{n}(\%)\end{array}$ & Total $\mathrm{n}=49$ & Group $1 \mathrm{n}=7$ & Group $2 \mathrm{n}=32$ & Group $3 \mathrm{n}=10$ & $p$-value \\
\hline $\begin{array}{l}\text { Preop MR (0 } \\
=\text { none, } 1= \\
\text { trivial, } 2= \\
\text { mild, } 3= \\
\text { moderate, } 4= \\
\text { severe) }\end{array}$ & $0.86 \pm 0.68$ & $0.71 \pm 0.49$ & $0.88 \pm 0.7$ & $0.9 \pm 0.74$ & 0.835 \\
\hline $\begin{array}{l}\text { Postop AI }(0 \\
=\text { none, } 1= \\
\text { trivial, } 2= \\
\text { mild, } 3= \\
\text { moderate, } 4= \\
\text { severe })\end{array}$ & $1.4 \pm 0.9$ & $2.2 \pm 1.0$ & $1.3 \pm 0.9$ & $1.2 \pm 0.6$ & 0.030 \\
\hline $\begin{array}{l}\text { Greater Than } \\
\text { Trivial Postop } \\
\text { AI }\end{array}$ & $23(47)$ & $6(85)$ & $14(44)$ & $3(30)$ & 0.064 \\
\hline $\begin{array}{l}\text { Greater Than } \\
\text { Mild Postop } \\
\text { AI }\end{array}$ & $6(12)$ & $4(57)$ & $2(6)$ & $0(0)$ & $<0.001$ \\
\hline $\begin{array}{l}\text { Postop MR ( } 0 \\
=\text { none, } 1= \\
\text { trivial, } 2= \\
\text { mild, } 3= \\
\text { moderate, } 4= \\
\text { severe })\end{array}$ & $1.0 \pm 0.8$ & $1.1 \pm 0.4$ & $1.1 \pm 0.9$ & $0.8 \pm 0.4$ & 0.586 \\
\hline $\begin{array}{l}\text { Most Recent } \\
\text { AI }(0=\text { none, } \\
1=\text { trivial, } 2 \\
=\text { mild, } 3= \\
\text { moderate, } 4= \\
\text { severe })\end{array}$ & $1.5 \pm 0.9$ & - & $1.5 \pm 1.0$ & $1.6 \pm 0.8$ & 0.926 \\
\hline $\begin{array}{l}\text { Most Recent } \\
\text { Greater Than } \\
\text { Trivial AI }\end{array}$ & $20(50)$ & - & $15(50)$ & $5(50)$ & 1.000 \\
\hline $\begin{array}{l}\text { Most Recent } \\
\text { Greater Than } \\
\text { Mild AI }\end{array}$ & $7(18)$ & - & $6(20)$ & $1(10)$ & 0.471 \\
\hline $\begin{array}{l}\text { Most Recent } \\
\text { MR }(0=\text { none, } \\
1=\text { trivial, } 2 \\
=\text { mild, } 3= \\
\text { moderate, } 4= \\
\text { severe })\end{array}$ & $1.2 \pm 0.6$ & - & $1.2 \pm 0.9$ & $1.2 \pm 0.6$ & 0.921 \\
\hline $\begin{array}{l}\text { Perfusion } \\
\text { Time, min }\end{array}$ & $197 \pm 57$ & $160 \pm 20$ & $177 \pm 41$ & $282 \pm 28$ & $<0.001$ \\
\hline $\begin{array}{l}\text { Cross-Clamp } \\
\text { Time, min }\end{array}$ & $143 \pm 52$ & $108 \pm 23$ & $123 \pm 28$ & $230 \pm 24$ & $<0.001$ \\
\hline $\begin{array}{l}\text { Preop Aortic } \\
\text { Annulus, mm }\end{array}$ & $28 \pm 5$ & $31 \pm 6$ & $26 \pm 5$ & $29 \pm 4$ & 0.064 \\
\hline
\end{tabular}




\begin{tabular}{|c|c|c|c|c|c|}
\hline $\begin{array}{l}\text { Variable } \\
\text { Median }+ \text { std } \\
\text { or } n(\%)\end{array}$ & Total $n=49$ & Group $1 \mathrm{n}=7$ & Group $2 \mathrm{n}=32$ & Group $3 n=10$ & $p$-value \\
\hline $\begin{array}{l}\text { Postop Aortic } \\
\text { Annulus, mm }\end{array}$ & $22 \pm 3$ & $26 \pm 6$ & $22 \pm 2$ & $21 \pm 2$ & 0.027 \\
\hline
\end{tabular}

Table 2. Stats by reintervention. Group $1=$ no reintervention. Group $2=$ reintervention.

\begin{tabular}{|c|c|c|c|c|}
\hline $\begin{array}{l}\text { Variable Median } \\
+ \text { std or } \mathbf{n}(\%)\end{array}$ & Total $n=49$ & Group $1 \mathrm{n}=36$ & Group $2 \mathrm{n}=13$ & $p$-value \\
\hline Age, years & $20 \pm 6$ & $20 \pm 5$ & $17 \pm 7$ & 0.121 \\
\hline Male sex & $36(73)$ & $31(86)$ & $12(92)$ & 0.559 \\
\hline \multicolumn{5}{|l|}{ Prior Procedure } \\
\hline David & $32(65)$ & $26(72)$ & $6(46)$ & \multirow[t]{3}{*}{$<0.001$} \\
\hline Yacoub & $7(14)$ & $0(0)$ & $7(54)$ & \\
\hline Modified Yacoub & $10(20)$ & $10(28)$ & $0(0)$ & \\
\hline \multicolumn{5}{|l|}{ Operation, kg } \\
\hline $\begin{array}{l}\text { Postop Length of } \\
\text { Stay, days }\end{array}$ & $5 \pm 2$ & $5 \pm 2$ & $6 \pm 3$ & 0.235 \\
\hline Follow-Up, years & $5 \pm 5$ & $3 \pm 4$ & $11 \pm 5$ & $<0.001$ \\
\hline Follow-Up to Last & $8 \pm 6$ & $5 \pm 4$ & $13 \pm 5$ & $<0.001$ \\
\hline \multicolumn{5}{|l|}{$\begin{array}{l}\text { Known Alive, } \\
\text { years }\end{array}$} \\
\hline CTD & $18(37)$ & $14(39)$ & $4(31)$ & 0.603 \\
\hline Prior Ross & $25(51)$ & $17(47)$ & $8(62)$ & 0.376 \\
\hline \multicolumn{5}{|l|}{ Procedure } \\
\hline Leaflet & $15(31)$ & $11(31)$ & $4(31)$ & 0.989 \\
\hline \multicolumn{5}{|l|}{ Manipulation } \\
\hline \multicolumn{5}{|l|}{ Etiology } \\
\hline Congenital & $21(49)$ & $17(47)$ & $4(57)$ & 0.584 \\
\hline Bicuspid & $14(32)$ & $11(31)$ & $3(43)$ & \\
\hline Acquired & $7(16)$ & $7(19)$ & $0(0)$ & \\
\hline Other & $1(2)$ & $1(3)$ & $0(0)$ & \\
\hline Redo Sternotomy & $28(57)$ & $20(56)$ & $8(62)$ & 0.709 \\
\hline Concomitant & $31(63)$ & $25(69)$ & $6(46)$ & 0.135 \\
\hline \multicolumn{5}{|l|}{ Procedure } \\
\hline Death & $2(4)$ & $1(3)$ & $1(8)$ & 0.443 \\
\hline $\begin{array}{l}\text { Time to Death, } \\
\text { years }\end{array}$ & $5 \pm 8$ & 0 & 11 & - \\
\hline $\begin{array}{l}\text { Follow-Up to } \\
\text { Most Recent }\end{array}$ & $5 \pm 5$ & $4 \pm 4$ & $9 \pm 6$ & 0.002 \\
\hline \multicolumn{5}{|l|}{ Echo, years } \\
\hline $\begin{array}{l}\text { Preop AI }(0= \\
\text { none, } 1=\text { trivial, } \\
2=\text { mild, } 3= \\
\text { moderate, } 4= \\
\text { severe })\end{array}$ & $1.9 \pm 1.0$ & $2.0 \pm 1.1$ & $1.8 \pm 0.8$ & 0.625 \\
\hline $\begin{array}{l}\text { Greater Than } \\
\text { Trivial Preop AI }\end{array}$ & $34(69)$ & $26(72)$ & $8(62)$ & 0.474 \\
\hline
\end{tabular}




\begin{tabular}{|c|c|c|c|c|}
\hline $\begin{array}{l}\text { Variable Median } \\
+ \text { std or } n(\%)\end{array}$ & Total $n=49$ & Group $1 \mathrm{n}=36$ & Group $2 \mathrm{n}=13$ & $p$-value \\
\hline $\begin{array}{l}\text { Greater Than } \\
\text { Mild Preop AI }\end{array}$ & $16(33)$ & $12(33)$ & $4(31)$ & 0.866 \\
\hline $\begin{array}{l}\text { Preop MR }(0= \\
\text { none, } 1=\text { trivial, } \\
2=\text { mild, } 3= \\
\text { moderate, } 4= \\
\text { severe })\end{array}$ & $0.9 \pm 0.7$ & $0.8 \pm 0.6$ & $1.0 \pm 0.8$ & 0.38 \\
\hline $\begin{array}{l}\text { Postop AI }(0= \\
\text { none, } 1=\text { trivial, } \\
2=\text { mild, } 3= \\
\text { moderate, } 4= \\
\text { severe })\end{array}$ & $1.4 \pm 0.9$ & $1.1 \pm 0.7$ & $2.2 \pm 0.6$ & $<0.001$ \\
\hline $\begin{array}{l}\text { Greater Than } \\
\text { Trivial Postop AI }\end{array}$ & $23(47)$ & $12(33)$ & $11(85)$ & 0.001 \\
\hline $\begin{array}{l}\text { Greater Than } \\
\text { Mild Postop AI }\end{array}$ & $6(12)$ & $0(0)$ & $6(46)$ & $<0.001$ \\
\hline $\begin{array}{l}\text { Postop MR }(0= \\
\text { none, } 1=\text { trivial, } \\
2=\text { mild, } 3= \\
\text { moderate, } 4= \\
\text { severe })\end{array}$ & $1.0 \pm 0.8$ & $0.8 \pm 0.7$ & $1.4 \pm 0.9$ & 0.05 \\
\hline
\end{tabular}

\section{Citations:}

1. Dearani JA, Connolly HM, Martinez R, Fontanet H, Webb GD. Caring for adults with congenital cardiac disease: successes and challenges for 2007 and beyond. Cardiol Young. 2007;17 Suppl 2:87-96.

2. Niwa K, Siu SC, Webb GD, Gatzoulis MA. Progressive aortic root dilatation in adults late after repair of tetralogy of Fallot.Circulation. 2002;106:1374-1378.

3. Kim WH, Seo JW, Kim SJ, Song J, Lee J, Na CY. Aortic dissection late after repair of tetralogy of Fallot. Int J Cardiol. 2005;101:515-516.

4. Mokashi SA, Svensson LG. Guidelines for the management of thoracic aortic disease in 2017. Gen Thorac Cardiovasc Surg.2019;67:59-65.

5. Zalzstein E, Hamilton R, Zucker N, Diamant S, Webb G. Aortic dissection in children and young adults: diagnosis, patients at risk, and outcomes. Cardiol Young. 2003;13:341-344.

6. Konstantinov IE, Fricke TA, d'Udekem Y, Robertson T. Aortic dissection and rupture in adolescents after tetralogy of Fallot repair.J Thorac Cardiovasc Surg. 2010;140:e71-73.

7. Buratto E, Konstantinov IE. Valve-sparing aortic root surgery in children and adults with congenital heart disease. J Thorac Cardiovasc Surg. 2020.

8. Erbel R, Aboyans V, Boileau C, et al. 2014 ESC Guidelines on the diagnosis and treatment of aortic diseases: Document covering acute and chronic aortic diseases of the thoracic and abdominal aorta of the adult. The Task Force for the Diagnosis and Treatment of Aortic Diseases of the European Society of Cardiology (ESC). Eur Heart J.2014;35:2873-2926.

9. Stulak JM, Dearani JA, Burkhart HM, Sundt TM, Connolly HM, Schaff HV. Does the dilated ascending aorta in an adult with congenital heart disease require intervention? J Thorac Cardiovasc Surg.2010;140:S5257; discussion S86-91. 
10. Dearani JA, Burkhart HM, Stulak JM, Sundt TM, Schaff HV. Management of the aortic root in adult patients with conotruncal anomalies. Semin Thorac Cardiovasc Surg Pediatr Card Surg Annu.2009:122-129.

11. Vricella LA, Cameron DE. Valve-Sparing Aortic Root Replacement in Pediatric Patients: Lessons Learned Over Two Decades.Semin Thorac Cardiovasc Surg Pediatr Card Surg Annu.2017;20:56-62.

12. Mookhoek A, Korteland NM, Arabkhani B, et al. Bentall Procedure: A Systematic Review and MetaAnalysis. Ann Thorac Surg. 2016;101:1684-1689.

13. Salmasi MY, Theodoulou I, Iyer P, et al. Comparing outcomes between valve-sparing root replacement and the Bentall procedure in proximal aortic aneurysms: systematic review and meta-analysis. Interact Cardiovasc Thorac Surg. 2019;29:911-922.

14. Flynn CD, Tian DH, Wilson-Smith A, et al. Systematic review and meta-analysis of surgical outcomes in Marfan patients undergoing aortic root surgery by composite-valve graft or valve sparing root replacement. Ann Cardiothorac Surg. 2017;6:570-581.

15. Ouzounian M, Rao V, Manlhiot C, et al. Valve-Sparing Root Replacement Compared With Composite Valve Graft Procedures in Patients With Aortic Root Dilation. J Am Coll Cardiol. 2016;68:1838-1847.

16. Roubertie F, Ben Ali W, Raisky O, Tamisier D, Sidi D, Vouhe PR. Aortic root replacement in children: a word of caution about valve-sparing procedures. Eur J Cardiothorac Surg.2009;35:136-140.

17. Baliulis G, Ropponen JO, Salmon TP, Kaarne MO. Valve-sparing aortic root replacement in adult patients previously operated for congenital heart defects: an initial experience. Eur J Cardiothorac Surg. 2016;50:155-159.

18. David TE. Contemporary outcomes of surgery for aortic root aneurysms: A propensity-matched comparison of valve-sparing and composite valve graft replacement. J Thorac Cardiovasc Surg.2015;150:1130-1131.

19. David TE, Feindel CM, David CM, Manlhiot C. A quarter of a century of experience with aortic valve-sparing operations. J Thorac Cardiovasc Surg. 2014;148:872-879; discussion 879-880.

20. Fraser CD, 3rd, Liu RH, Zhou X, et al. Valve-sparing aortic root replacement in children: Outcomes from 100 consecutive cases.J Thorac Cardiovasc Surg. 2019;157:1100-1109. 